\title{
Kontekst geopolityczny kryzysu na Ukrainie (2013-2014) i zaangażowanie wladz polskich w jego rozwiązanie
}

Streszczenie: W artykule przedstawiono specyfikę zaangażowania podmiotów międzynarodowych w konflikt na Ukrainie na przełomie 2013-2014 r. Atrakcyjność tego państwa wynikała w zasadniczej mierze z jego położenia geopolitycznego oraz pozycji jako kraju buforowego między Wschodem a Zachodem. Omówiono ponadto działania władz polskich podejmowane w kierunku zażegnania sporu, wynikające z rosnącego poczucia zagrożenia ze strony Federacji Rosyjskiej.

Słowa kluczowe: kryzys na Ukrainie 2013-2014, EuroMajdan, geopolityka

\section{Wprowadzenie}

T istopadowe wydarzenia 2013 r. na Ukrainie spowodowały, że państwo to znalazło się w stanie poważnego kryzysu, który z biegiem czasu przybrał oblicze ustrojowe, polityczne, gospodarcze, etniczne i społeczne, w efekcie doprowadzając do konfliktu militarnego z Rosją.

Zapowiedź prezydenta Ukrainy Wiktora Janukowycza, że na szczycie Partnerstwa Wschodniego ${ }^{1}$ w Wilnie (29 listopada 2013 r.) nie podpisze

${ }^{1}$ Partnerstwo Wschodnie (PW) - pomocniczy program określający wymiar wschodni polityki Unii Europejskiej w ramach Europejskiej Polityki Sąsiedztwa. Obejmował realizację polityki rozszerzenia UE oraz zacieśnienia stosunków z zewnętrznymi podmiotami m.in. państwami: Białorusią, Ukrainą, Mołdawią, Gruzją, Azerbejdżanem i Armenią. Efektem realizacji projektu miały być preferencje handlowe, ułatwienia wizowe i programy pomocowe. Projekt Partnerstwa został zapoczątkowany działaniami dyplomacji polskiej, wspieranymi przez Szwecję i zainaugurowany w Pradze w 2009 r. Wewnątrz PW rozegrała się wówczas rywalizacja między koncepcją euroazjatycką i euroatlantycką. Pierwsza z nich zakładała włączenie do programu Federacji Rosyjskiej celem zbliżenia Wschodu i Zachodu, co miało skutkować wyrugowaniem ingerencji USA z rejonu kontynentu europejskiego. Koncepcja 
umowy o stowarzyszeniu z Unią Europejską (UE), była komentowana szeroko $\mathrm{w}$ środkach masowego przekazu jako porażka polityki Zachodu i otwarcie drogi do reintegracji Ukrainy z Rosją. Zajęcie i późniejsza aneksja Krymu oraz następujące po niej rosyjskie wsparcie dla separatystów we wschodniej części Ukrainy, poważnie osłabiły poczucie bezpieczeństwa wśród państw Europy. Spowodowało to załamanie dotychczasowej polityki bezpieczeństwa i konieczność przewartościowania stosowanych dotychczas metod jego zapewnienia nie tylko na Ukrainie, ale także w krajach z nią sąsiadujących, jak również krajach Europy Zachodniej, a w znacznym stopniu nawet w strefie euroatlantyckiej.

Do krajów bezpośrednio zainteresowanych kierunkiem zmian na Wschodzie należała również Polska, która m.in. z uwagi na bliskie sąsiedztwo ze skonfliktowanymi krajami oraz zależności ekonomiczne, została zobligowana do zajęcia stanowiska w tym sporze również jako aktywny członek Unii Europejskiej oraz NATO, częściowo pełniąc rolę kreatora unijnej polityki wschodniej. Tak zdecydowane stanowisko Polski wobec kryzysu na Ukrainie motywowane było faktem, że państwo ukraińskie od zawsze stanowiło swoisty bufor odgradzający od Rosji. Stabilna sytuacja na Ukrainie leżała więc w interesie Polski, bowiem zwiększało to prawdopodobieństwo zmniejszenia zagrożenia ze strony Rosji. W demokratyzacji Ukrainy upatrywano ponadto gwarancji skuteczniejszej realizacji polskich interesów oraz korzyści dla całej UE. Strona polska, upatrując głównej przyczyny kryzysu na Ukrainie w działaniach Rosji, podjęła zatem szereg działań dyplomatycznych zmierzających do izolowania tego państwa na arenie międzynarodowej i uniemożliwiania rozwoju jego imperialnych dążeń.

\section{Kryzys ukraiński - okoliczności i przebieg}

Początków kryzysu na Wschodzie upatruje się, jak już wspomniano, od momentu odstapienia od podpisania umowy stowarzyszeniowej z UE przez prezydenta Ukrainy - Wiktora Janukowycza. Zawieszenie przygotowań tłumaczono potencjalnym pogorszeniem relacji handlowych z Rosją oraz brakiem propozycji zadośćuczynienia za ewentualne straty, ze strony Unii wobec państwa ukraińskiego (Zięba, 2014, s. 17). W odpowiedzi na podpisanie przez Ukrainę dokumentów stowarzyszeniowych,

euroatlantycka przyjmowała narzucony przez amerykańskie ośrodki wpływu paradygmat konfliktu cywilizacyjnego między Rosją a Zachodem. 
Rosja miała bowiem zagrozić wprowadzeniem restrykcji gospodarczych, które byłyby boleśnie odczuwane przez nadwyrężoną gospodarkę kraju. Rezygnacja z podpisania umowy stowarzyszeniowej wywołała gwałtowne protesty społeczne w Kijowie i innych miastach zachodniej Ukrainy.

$\mathrm{W}$ początkowym okresie buntu demonstranci domagali się zmiany stanowiska władz i podpisania umowy stowarzyszeniowej. W kolejnych tygodniach następowała radykalizacja postulatów, prowadząc do sformułowania żądań zmiany całego systemu władzy, odwołania aktualnego rządu oraz dymisji prezydenta Janukowycza. Manifestacje te przerodziły się z czasem w okupację centralnego placu w stolicy tzw. Majdanu Niepodległości (EuroMajdanu), która miała miejsce w okresie od 21 listopada 2013 r. do 9 lipca 2014 r. Była to największa fala protestów zwolenników integracji z UE od czasu „pomarańczowej rewolucji” (2004-2005). Konflikt pomiędzy władzą a obywatelami doprowadził do obalenia głowy państwa $\mathrm{w}$ wyniku pozakonstytucyjnego przewrotu państwowego (22-26 lutego 2014 r.). Prezydent będąc, z jednej strony, szantażowanym gospodarczo przez Rosję, z drugiej będąc naciskanym przez Unię Europejską oraz reprezentantów najbardziej radykalnych ugrupowań ukraińskiej sceny politycznej, podjął decyzję o opuszczeniu kraju i udał się do Rosji. Ów przewrót ukonstytuował zmianę władzy i dał początek konfliktowi na dużą skalę, który przerodził się w wojnę domową na wschodzie Ukrainy. Stanowił ponadto katalizator rozpadu państwa i rosyjskiej interwencji w obronie separatystów na Wschodzie i na Krymie. Majdan zaognił również stosunki między Zachodem a Rosją. Nowopowstały rząd zwrócił się bowiem o pomoc do państw zachodnich ogłaszając gotowość szybkiego zawarcia umowy stowarzyszeniowej z Unią Europejską. Na tę prośbę odpowiedziały Stany Zjednoczone i sama Unia, uznając nowe władze i zapowiadając udzielenie pomocy pogrążonej w kryzysie Ukrainie. W odpowiedzi na to władze Rosji oskarżyły państwa zachodnie o wspieranie radykalnych i faszyzujących grup z zachodniej Ukrainy (Zięba, 2014, s. 18). Federacja Rosyjska zaniepokojona zmianą istniejącego porządku, zakwestionowała dotychczasowe, zgodne z ustaleniami międzynarodowymi z początku lat dziewięćdziesiątych, terytorialne status quo. Wydarzenia na Ukrainie potraktowano w Moskwie jako próbę wyrwania przez Zachód Kijowa spod „prawowitej” kontroli i wpływów Rosji.

W efekcie okrzepnięcia - po wyborach prezydenckich (25 maja 2014 r.) i parlamentarnych (26 października 2014 r.) - nowego ładu konstytucyjnego Ukrainy doszło do formalnej przebudowy systemu politycznego kraju (Potocki, 2014, s. 66-95). Rada Najwyższa Ukrainy 
tymczasowo powierzyła wówczas obowiązki głowy państwa swojemu przewodniczącemu - Ołeksandrowi Turczynowowi. Wkrótce powołano nowy rząd na czele z liderem partii Batkiwszczyzna - Arsenijem Jaceniukiem. W skład rządu weszli działacze tej partii wraz z członkami ugrupowania Swoboda, jak również przywódcy EuroMajdanu. Jedną z pierwszych decyzji nowopowstałego rządu było anulowanie ustawy o podstawach polityki językowej z 2012 r., która nadawała uprzywilejowany status językom mniejszości narodowych. Była ona korzystna dla grup etnicznych zamieszkujących na wschodzie i południu Ukrainy m.in. dla Rosjan. Anulowanie tej ustawy wywołało oburzenie w wielu regionach Ukrainy i spotkało się z kolejnym ostrym protestem Federacji Rosyjskiej oraz innych państw tj.: Węgry, Słowacja, Rumunia czy Bułgaria. Decyzję nowych władz Rosja zinterpretowała jako nacjonalistyczną, antyrosyjską prowokację ze strony Ukrainy, jednocześnie zapowiadając ochronę Rosjan zamieszkujących tereny państwa ukraińskiego.

Na przełomie lutego i marca 2014 r. rozpoczął się tzw. „,kryzys krymski”, będący (co później prezydent Władimir Putin przyznał wprost) aneksją terytorium obcego państwa przy wykorzystaniu rosyjskich żołnierzy. Przy udziale swoich wojsk, stacjonujących w bazie marynarki wojennej w Sewastopolu, Federacja Rosyjska wsparła secesję Krymu, zamieszkałego w dużej mierze przez Rosjan. Bowiem z punktu widzenia Moskwy Półwysep Krymski stanowił naturalny przyczółek dla zakrojonych na szeroką skalę, długofalowych działań na rzecz przywrócenia rosyjskiej kontroli geopolitycznej nad Ukrainą. Na tych terenach doszło następnie do ukonstytuowania się dwóch quasi-państwowych tworów: „Donieckiej Republiki Ludowej” oraz „Ługańskiej Republiki Ludowej”. Otworzyło to nowy etap kryzysu, który przerodził się w krwawą wojnę domową (Kowalczyk, 2015). Separatyści, wspierani przez rosyjskie władze doprowadzili do przyłączenia wspomnianego Półwyspu Krymskiego wraz z Sewastopolem do Rosji. Legalność aneksji potwierdziło przeprowadzone referendum. Według oficjalnych statystyk 96,57\% uczestników (przy frekwencji 84\%) (Referendum na Krymie) opowiedziało się za przyłączeniem do Rosyjskiej Federacji. Nastapiło to oficjalnie 21 marca 2014 r. Przyłączenie Krymu do Rosji zachęciło inne regiony Ukrainy wschodniej do podjęcia działań w celu wyjścia ze składu państwa ukraińskiego, bądź uzyskania w nim szerokiej autonomii.

Równolegle do wydarzeń krymskich, w centralnych miastach Ukrainy odbywały się wiece proukraińskie, których uczestnicy żądali przywrócenia dawnego porządku w państwie, jak również demonstracje proro- 
syjskie - popierające działania Władimira Putina na wschodzie Ukrainy. Pogrążone w chaosie państwo ukraińskie, działając pod doradztwem politycznym i dzięki pomocy w pozyskiwaniu sprzętu wojskowego USA i UE - zaczęło realnie bronić swej integralności terytorialnej (Zięba, 2014, s. 19). Referendum i aneksja Krymu zostały ostro potępione przez nowe władze Ukrainy oraz państwa zachodnie, które zawiesiły udział Rosji w Grupie G- $8^{2}$ oraz nałożyły pierwsze sankcje na to państwo. Polegały one na zakazie podróżowania do USA i krajów UE oraz zamrożenie aktywów trzydziestu trzech osób odpowiedzialnych za działania zagrażające integralności terytorialnej, suwerenności i niepodległości (UE rozszerza). Państwa zachodnie oskarżyły ponadto Rosję o złamanie prawa międzynarodowego i eskalowanie konfliktu, zapowiadając kolejne sankcje ekonomiczne wobec tego państwa. W geście symbolicznego poparcia dla wschodniego sąsiada Wspólnoty Europejskiej i tymczasowych władz w Kijowie, w marcu 2014 r. UE w Brukseli podpisała z Ukrainą polityczną część umowy stowarzyszeniowej. W kwietniu 2014 r. podjęto jednak rokowania z Rosją w sprawie załagodzenia konfliktu na Ukrainie. Rezultatem rozmów było zawarcie porozumienia genewskiego (17 kwietnia 2014 r.) podpisanego przez szefów dyplomacji państw: Rosji, Ukrainy, USA i UE. Porozumienie to zawierało m.in.: apele do „wszystkich stron konfliktu" o powstrzymanie się od przemocy, rozbrojenie nielegalnych grup zbrojnych oraz zaprzestanie okupacji budynków i miejsc publicznych oraz zobowiązanie Ukrainy do konstytucyjnego procesu federalizacji państwa z udziałem wszystkich regionów (Genewskie porozumienie). Deklaracja okazała się bardzo niekorzystna dla Ukrainy, bowiem nie nakładała żadnych zobowiązań na Rosję, a wyłącznie na Kijów, sytuując państwo rosyjskie na pozycji „recenzenta” pilnującego wykonywania tych zobowiązań przez Ukrainę (Kuczyński).

\section{Strategiczna pozycja Ukrainy na arenie międzynarodowej}

Obserwacja wydarzeń na Ukrainie zimą 2013-2014 r. zrodziła pytania o motywacje podmiotów międzynarodowych angażujących się w rozwiązanie konfliktu?, czy wynikały one z mocnej pozycji politycznej i ekonomicznej Ukrainy?, czy może inne czynniki miały na to wpływ?

${ }^{2}$ Grupa najbardziej wpływowych, najbogatszych państw świata, nieformalnie przewodzących gospodarce światowej. Należą do niej państwa: Stany Zjednoczone, Kanada, Japonia, Niemcy, Francja, Wielka Brytania, Włochy oraz Rosja. 
Odpowiedzi na te pytania udzielił w znacznym stopniu Zbigniew Brzeziński, który twierdził, że pozycja Ukrainy „nie wynika z potęgi czy ambicji, lecz raczej z ważnego położenia geograficznego i skutków jej potencjalnej niestabilności dla zachowań graczy geostrategicznych. [...] Bez Ukrainy Rosja przestaje być imperium euroazjatyckim [...], jeżeli jednak Moskwa ponownie zdobędzie władzę nad Ukrainą, wraz z 52 milionami obywateli, ogromnymi bogactwami naturalnymi i dostępem do Morza Czarnego, automatycznie odzyska możliwość stania się potężnym imperium, spinającym Europę i Azję" (Brzeziński, 1998, s. 56). Doradca prezydenta Cartera w zakresie bezpieczeństwa usytuował Ukrainę jako jedną z pięciu - obok Azerbejdżanu, Korei Południowej, Turcji i Iranu - „osi geopolitycznych”, na której toczy się gra o panowanie nad światem (Brzeziński, 1997, s. 40-41). Zatem to nie potencjał ekonomiczny, czy powierzchniowy państwa zadecydował o pozycji Ukrainy, ale właśnie specyficzne usytuowanie geograficzne, które determinuje geopolityczne znaczenie tego państwa jako swoistego zwornika między Wschodem i Zachodem. Potencjał Ukrainy mieści się oprócz jej kluczowego położenia geostrategicznego, w dostępie do Morza Czarnego oraz perspektywie transportowej, umożliwiającej dywersyfikację przepływu surowców energetycznych z Rosji i regionu Morza Kaspijskiego do Europy Zachodniej i Południowej. Fakt ten stanowi istotę konfliktu na Ukrainie i wyjaśnia globalną geopolityczną konkurencję mocarstw o wpływy na tym obszarze. Strategiczne znaczenie Ukrainy przejawia się również w tym, że sam fakt jej istnienia wyznacza w jakimś sensie warunki wyjścia Rosji z ,interioru” euroazjatyckiego na Południe i Zachód, pozbawiając ją zasobów niezbędnych do prowadzenia polityki imperialnej i stwarzając jednocześnie tarczę ochronną dla Europy Środkowej. Rodzi to konieczność balansowania Ukrainy między Wschodem a Zachodem, stając się obszarem rywalizacji i ścierania się interesów z jednej strony Federacji Rosyjskiej, a z drugiej Stanów Zjednoczonych, NATO, Unii Europejskiej, w tym także Polski (Stolarczyk, 2014, s. 41-42). Wymusiło to na ukraińskich władzach prowadzenie polityki wielowektorowości, polegającej na balansowaniu między światem euroatlantyckim a Eurazją. Państwo to przez lata nie mogło zdecydować się na kierunek strategicznych sojuszy - czy związać się z Rosją, czy z Zachodem - próbowało zachować równowagę między Europą, Stanami Zjednoczonymi i Rosją. Taka polityka wymagała jednak silnej, zintegrowanej władzy, lojalnych elit i potencjału państwowego. Żadnego z tych elementów Ukraina nie posiadała (Szczęśniak). 
Ukraina jako niepodległe państwo, na mapie Europy, pojawiła się w 1991 r. (24 sierpnia 1991 r.), kiedy to bezpośrednio po upadku puczu moskiewskiego, proklamowała niepodległość. Pierwszym państwem na świecie, które uznało ten fakt była Polska (2 grudnia 1991 r.), ujawniając tym samym ówczesne priorytety polskiej polityki wschodniej. Po odzyskaniu niepodległości władze Ukrainy, próbując zaspokoić oczekiwania wszystkich zainteresowanych stron, tj. Rosji, USA, Polski czy Niemiec, składały szereg nie zawsze spójnych deklaracji. Ta wielowektorowość Ukrainy utrudniała jednoznaczną identyfikację kraju jako prozachodniego lub prowschodniego podmiotu. Zdecydowanie proeuropejski kierunek przybrała po „pomarańczowej rewolucji” (2004-2005) oraz po wyborze Wiktora Juszczenki na urząd prezydenta. W kształtowaniu ukraińsko-unijnych relacji istotną rolę odgrywała Polska, promując ukraińskie aspiracje na forum UE, a podczas „pomarańczowej rewolucji" była inicjatorem szerszego zainteresowania ukraińską sprawą w Parlamencie Europejskim, a także w innych krajach (Barburska, 2006, s. 51-52).

Współcześnie Ukraina postrzegana jest jako państwo, dopiero poszukujące swego miejsca w jednoczącej się Europie. Wybór Ukrainy między zbliżeniem do Wschodu lub Zachodu, wydaje się trudny i wciąż otwarty. Sygnowanie umowy stowarzyszeniowej z UE zrodziło nadzieję na perspektywę integracji z Zachodem, ale także stało się przyczyną wzmożonej aktywności dyplomacji rosyjskiej, która upatruje w Ukrainie członka Unii Celnej. Zarówno Unia Europejska, jak i Federacja Rosyjska są dla Ukrainy ważnymi punktami odniesienia, przy czym wybór jednoznacznej drogi rozwoju będzie miał dominujący wpływ na pozycję Ukrainy pod względem geopolitycznym, gospodarczym, jak również w dziedzinie bezpieczeństwa. Dokonanie wyboru jest bardzo trudne biorąc pod uwagę wielowiekową zależność polityczną, ekonomiczną i kulturową od Moskwy oraz próbę uniezależnienia się poprzez utrzymanie równowagi między Rosją a UE. W związku z tym, że stabilizacja i bezpieczeństwo w Eurazji leży w interesie USA, wspierają one integrację Ukrainy z NATO i UE. Stanowi to jednocześnie natychmiastową reakcję Rosji, która postrzega Ukrainę jako część byłego Związku Radzieckiego, a tym samym jako część swojej strefy wpływów. Dlatego też w kontekście stosunków USA-NATO-Rosja, Ukraina pozostaje w centrum uwagi, a kierunek jej integracji - wschodni lub zachodni - określi orientację jej polityki zagranicznej. 


\section{Znaczenie Ukrainy dla Federacji Rosyjskiej}

Dla Federacji Rosyjskiej, zamieszkiwana przez liczną mniejszość rosyjską oraz powiązana kulturowo i historycznie, Ukraina stanowi jeden z krajów tzw. bliskiej zagranicy. Do tego obszaru można zakwalifikować całą przestrzeń postradziecką, którą tworzą byłe radzieckie republiki związkowe, stanowiące przed 1991 r. główne jednostki terytorialno-narodowościowego i administracyjnego podziału Związku Radzieckiego (Świder, 2014, s. 98). Ukraina stanowi ponadto bardzo ważną część rosyjskiego myślenia geopolitycznego, w ramach którego konstruowana jest rola Rosji w systemie międzynarodowym oraz element wyobrażenia o misji dziejowej i globalnej pozycji tego kraju. W przekonaniu Moskwy brak rosyjskiej kontroli nad wybrzeżem czarnomorskim zagraża istnieniu samej Rosji jako samodzielnego państwa (Świder, 2014, s. 111). Nie dziwi więc brak zgody na geopolityczne instalowanie się Zachodu (zwłaszcza Stanów Zjednoczonych) w kręgu obszaru „,bliskiej zagranicy”. Suwerenność Ukrainy jest bowiem negatywnym zjawiskiem dla rosyjskiej geopolityki, dlatego tak łatwo może prowadzić do konfliktu zbrojnego.

Od uzyskania niepodległości w $1991 \mathrm{r}$. Ukraina podejmowała wysiłki na rzecz kształtowania poprawnych relacji z Rosją, jak i stworzenia nowych ram współpracy z UE, która uosabiała potęgę gospodarczą, bezpieczeństwo i rozwój. Położenie geopolityczne Ukrainy sprzyjało takim relacjom, ale tylko do chwili kiedy stery władzy w Rosji objął Wladimir Putin (Tymanowski, 2014, s. 90), wówczas w zagranicznej polityce rosyjskiej zaczęto postrzegać obszar postradziecki jako wyłączną strefę wpływów Moskwy. Ukraina nie mogła więc liczyć na tolerancję i wsparcie Rosji w swojej proeuropejskiej drodze rozwoju. Wydarzenia przełomu 2013-2014 były więc dla Rosji sygnałem świadczącym o tym, że Ukraina może realizować własną, suwerenną politykę, która dla Kremla była nie do zaakceptowania. W dalszej perspektywie Federacja upatrywała bowiem w Ukrainie znaczącego ogniwa Unii Celnej, a następnie Euroazjatyckiej Unii Gospodarczej, które byłyby instrumentem gospodarczym imperialnej Rosji. Dlatego też w interesie Rosji leży dążenie do zintegrowania Ukrainy w ramach przestrzeni euroazjatyckiej. Nie powinno dziwić więc, że Moskwa, wymuszając na władzach w Kijowie korzystne dla siebie decyzje gospodarcze, pragnęła kontrolować politykę zagraniczną i politykę bezpieczeństwa Ukrainy oraz jej mające strategiczne znaczenie zasoby surowcowe oraz infrastrukturę tranzytową i transportową. Władze Rosji będąc ponadto zainteresowanymi utrzymaniem więzów kulturowych, 
językowych i religijnych z Ukrainą, konsekwentnie umacniają swoją pozycję w regionie i systematycznie odbudowują imperialną „strefę wpływów". Zrozumiały jest zatem opór Moskwy przed prozachodnim zwrotem Ukrainy i włączenie jej w amerykański system militarny, obejmujący aktualnie także Unię Europejską. Stanowiłoby to zagrożenie dla pozycji Rosji jako mocarstwa europejskiego. Plany rozszerzenia NATO o Ukrainę wywołują w Rosji zaniepokojenie, zaś ekspansja nad Dnieprem, będącym wojskowym protektoratem USA, Unii Europejskiej, traktowana jest na Kremlu jako wstępny krok w kierunku przejęcia strategicznej i geopolitycznej kontroli nad Ukrainą przez Zachód. Aneksja Krymu przez Federację Rosyjską zapobiegła, w opinii Rosjan, wrogiemu przejęciu przez Amerykanów w przyszłości rosyjskich baz wojennych na półwyspie przy aprobacie nowego rządu ukraińskiego (Świder, 2014, s. 115). Polityczna ekspansja Zachodu i jego struktur w kierunku postradzieckiego obszaru była interpretowana przez Rosję jako sabotowanie rosyjskich projektów jego integracji. Racją stanu Moskwy jest zatem eliminacja wpływów amerykańskich i NATO z obszaru jej bliskiej zagranicy oraz zapewnienie sobie nieskrępowanego dostępu do zasobów i przestrzeni geopolitycznej Ukrainy. W interesie Rosji leży zacieśnianie związków własnego rynku z rynkiem Ukrainy i kontrola nad strategicznymi gałęziami ukraińskiej gospodarki, w szczególności nad wytwarzaniem i przesyłaniem energii (Lasecki, 2015, s. 188). Dlatego też to niezdecydowanie Ukrainy w wyborze kierunku rozwoju wykorzystała Rosja, która ,podgrzewa” wszelkie konflikty i posługuje się nimi w celu realizacji własnych interesów geopolitycznych. Będąc państwem coraz bardziej zintegrowanym, prowadzonym przez silnego przywódcę, sporymi dochodami z ropy i gazu, posiada potężne środki wpływu i nacisku na Ukrainie poprzez rosyjską ludność, powiązania gospodarcze oraz kulturę i język.

\section{Znaczenie Ukrainy dla podmiotów zachodnich}

Zainteresowanie Zachodu (Unia Europejska, Stany Zjednoczone) rozwojem sytuacji na Ukrainie, jak już wspomniano, wynikało ze znaczącej roli tego państwa jako buforu oddzielającego od Federacji Rosyjskiej. Od momentu rozpadu ZSRR Ukraina znalazła się w orbicie zainteresowania unijnej polityki zagranicznej. Przejawem tego było m.in. podpisanie 14 czerwca 1994 r. Porozumienia o Partnerstwie i Współpracy zakładającego umacnianie wzajemnych więzi oraz wspieranie Ukrainy w tworze- 
niu i rozwoju instytucji demokratycznych. Starając się eksportować do Ukrainy swój model zarządzania, model ustrojowy, prawny, gospodarczy i kulturalny, Bruksela pragnęła rozszerzyć wokół siebie strefę bezpieczeństwa, stabilności i przewidywalności. Dla Europy bowiem Ukraina ma ogromne znaczenie i wszelkie zawirowania polityczne czy gospodarcze na jej terenie, mogąc mieć wpływ na rozwój sytuacji w regionie.

Rozpatrywanie położenia politycznego Ukrainy w kontekście „rozdarcia" między Wschodem a Zachodem nie tylko nawiązuje do jej położenia geograficznego, ale przede wszystkim dotyczy wyboru kierunku rozwoju państwa, którego konsekwencje będą także określały relacje między Federacją Rosyjską a Unią Europejską. W przekonaniu polityków zachodnich Ukraina stanowi klucz strategiczny do zapewnienia Europie bezpieczeństwa $\mathrm{z}$ racji swego potencjału geostrategicznego i geoekonomicznego, który sprawia że jest ona ważnym elementem przyszłej struktury bezpieczeństwa europejskiego. Dla państw zachodnich Ukraina stanowi także teren ekspansji politycznej, który miałby w przyszłości stać się częścią struktur euroatlantyckich, a to sprzyjałoby w przyszłości „krzepnięciu” demokracji rosyjskiej (Tymanowski, 2014, s. 13-14). Ukraina stałaby się wówczas konkurentem Rosji w stosunkach z Zachodem, co uwidoczniło się szczególnie po wydarzeniach na kijowskim Majdanie 2013-2014 r. Po raz pierwszy od rozpadu ZSRR Ukraina stała się płaszczyzną rywalizacji między Rosją a światem Zachodu nie tylko o sferę wpływu, ale głównie o kierunek i charakter przemian systemowych. Dla Kremla stanowi to swoisty egzamin z woli zaakceptowania trwałości przemian, jakie nastąpiły po rozpadzie ZSRR, a także powstrzymanie odradzania się tendencji neoimperialnych.

W interesie Unii leży więc stabilizacja polityczna i gospodarczo-finansowa Ukrainy, bowiem są one warunkiem wywiązywania się przez Kijów ze zobowiązań płatniczych wobec Gazpromu i bezpieczeństwa tranzytu rosyjskich nośników energii z Rosji przez Ukrainę do Unii Europejskiej. W przypadku narastania konfliktów rosyjsko-ukraińskich lub osłabienia zdolności płatniczych Ukrainy, obydwie strony posługując się wobec siebie instrumentami ekonomicznymi, podnosząc opłaty tranzytowe i wstrzymując eksport lub podkradając przesyłany gaz (Ukraina) lub też wstrzymując czy też podnosząc ceny dostaw (Rosja), zagrażają stabilności zaopatrzenia w gaz odbiorców unijnych, a tym samym bezpieczeństwu ekonomicznemu całej UE. Państwom zachodnim zależy ponadto na dostępie do zasobów i rynku ukraińskiego. Unii potrzebna jest zatem Ukraina stabilna, prowadząca przewidywalną politykę, dobrze 
zarządzana i rozwijająca się. W interesie UE jest więc zaangażowanie się $\mathrm{w}$ politykę ukraińską i kształtowanie sytuacji wewnętrznej $\mathrm{w}$ tym państwie w kierunku prowadzącym do osiagnnięcia tych celów (Lasecki, 2015, s. 184-185).

Instrumentem destabilizującym Ukrainę i paraliżującym dążenia tego państwa do integracji ze strukturami euroatlantyckimi są w znacznym stopniu ujawniające się podziały polityczno-terytorialne oraz nastroje społeczne w ukraińskim społeczeństwie. Napięcia w tych sferach narastają ilekroć któreś ze zwalczających się na Ukrainie mocarstw, zyskawszy chwilową przewagę nad konkurentami, próbuje dokonać jednostronnego przeorientowania Ukrainy na Wschód lub na Zachód. Gdy przewagę zyskuje opcja zachodnia, niepokoje społeczne i groźba secesji pojawiają się na Wschodzie i na południu kraju. Gdy zaś nadmierną przewagę zyskuje opcja wschodnia - Zachód pobudza swe aktywa w zachodniej części Ukrainy i w Kijowie.

\section{Znaczenie Ukrainy dla Polski}

Rzeczpospolita Polska od maja 2004 r. jest częścią Unii Europejskiej i jej interesy na Ukrainie znajdują się również w sferze zainteresowania Polski. Nasz kraj posiada ponadto swoje własne interesy wobec Ukrainy, które dotyczą głównie problematyki specyficznej dla stosunków polskoukraińskich i wspólnej przeszłości obu krajów. Obydwa kraje zbliżyła wspólnota interesów wobec Rosji, a sojusz z Polską miał pomóc Ukrainie $\mathrm{w}$ transformacji geopolitycznej z kraju postsowieckiego w państwo środkowoeuropejskie. W polityce zagranicznej i bezpieczeństwa Ukrainy Polska pełniła istotną rolę nie tylko w wymiarze regionalnego współlidera, ale również swoistego łącznika z Zachodem, promującego interesy ukraińskie (Tymanowski, 2014, s. 85). Państwo polskie wielokrotnie wykazało też ogromną przychylność i wyrozumiałość wobec Ukrainy³.

3 Jednym z przykładów tego była odmowa budowy drugiej nitki rurociagu Jamalskiego, umożliwiającego Rosji ominięcie Ukrainy w dostawach gazu do Europy. Władze polskie w Warszawie w 2001 r. wprost zadeklarowały, że dla Polski wspieranie Kijowa ważniejsze jest od korzyści ekonomicznych, jakie krajowi przyniosłaby realizacja tego projektu. Identyczne stanowisko polskie władze zajęły w kwietniu 2013 r., gdy Rosjanie złożyli kolejną propozycję, zdecydowanie odrzuconą przez polskie władze. Życzliwość dla sąsiada ze Wschodu obejmowała zarówno kwestie historyczne (niepodnoszenie tematu zbrodni na Wołyniu), jak i aktualne problemy gospodarcze 
To Polska właśnie była głównym inicjatorem polityki wschodniej NATO i UE, a po powstaniu samodzielnego państwa ukraińskiego jako pierwsza uznała jego niepodległość. Polska wreszcie była jednym z krajów, które bardzo aktywnie zaangażowały się w zażegnanie kryzysu na Ukrainie w 2014 r. Było to spowodowane potrzebą realizacji jednego z założeń polskiej polityki zagranicznej, polegającej na umacnianiu niepodległości i zachowaniu zachodniego kursu jako jednej z gwarancji, że Rosja nie powróci do polityki imperialnej. Warto zauważyć, że stosunki polskoukraińskie stanowią w dużej mierze funkcję polityki wobec Rosji oraz element strategii niesienia na Wschód „demokracji i praw człowieka”. Wynikałoby z tego założenie, że Rosja jest w Polsce traktowana jako główne zagrożenie dla bezpieczeństwa narodowego, a konsekwencją tego jest polityka odpychania Federacji Rosyjskiej od Europy, odgradzania pasem buforowym w postaci prozachodnich państw na wschodniej granicy (Zięba, 2014, s. 22). Swoista „,antyrosyjskość” ma w Polsce długą i bogatą tradycję, a konflikty z Rosją wpisane są już poniekąd w polską historię na stałe. Niemal od początku zmian ustrojowych po 1989 r. relacje polsko-rosyjskie nie układały się poprawnie. Sprzyjało temu przyjęcie przez Polskę jednoznacznie prozachodniego i proatlantyckiego kursu w polityce zagranicznej. Przejawem tego kierunku była akcesja do UE i NATO, a przede wszystkim przyjęcie przez Polskę koncepcji polityki wschodniej, opartej na tradycji neoprometeizmu i myśli geopolitycznej Jerzego Giedroycia ${ }^{4}$. Koncepcja ta polegała na wspieraniu tendencji an-

- Polska przez siedem lat znosiła ukraińskie embargo na eksport wieprzowiny i wołowiny. Wyrozumiałość przejawiała się także w ocenie kryzysu w styczniu 2006 r., kiedy to przerwano dostawy gazu do największych polskich zakładów przemysłowych. Ukraińcy w czasie surowych mrozów nielegalnie pobierali dla własnych potrzeb tranzytowy gaz z rurociągów, więc dostawy do Polski gwałtownie spadły. I chociaż Gazprom zwiększył dostawy przez Białoruś, a Ukraińcy przyznali się do swoich działań, w Polsce oficjalnie mówiono o „Rosji zakręcającej gazowy kurek”.

${ }^{4}$ Neoprometeizm to idea buntu przeciwko wszelkim potęgom ograniczającym wolność człowieka i całej ludzkości. Mityczny Prometeusz stał się bowiem symbolem dążeń narodów do wolności. W latach 20. i 30. XX w. termin ten oznaczał w praktyce współpracę polityczną i wojskową władz II Rzeczypospolitej z emigracyjnymi elitami narodów zniewolonych przez Związek Radziecki. Bezpośrednie autorstwo tej koncepcji przypisywane jest Józefowi Piłsudskiemu. W 1904 r. w memoriale do rządu japońskiego cel polityczny Polaków sformułował on w zdaniu, które można uznać za pierwszą definicję prometeizmu: „rozbicie państwa rosyjskiego na główne części składowe i usamowolnienie przemocą wcielonych w skład Imperium krajów". Wiele lat później jeden z działaczy ruchu prometejskiego, Włodzimierz Bączkowski, określił tenże ruch jako „wspólny front niepodległościowych przywódców i polityków, 
tyrosyjskich w byłych republikach radzieckich, a zwłaszcza na terenie państw ościennych. Przykładem było chociażby wspieranie ,pomarańczowej rewolucji" na Ukrainie, jak również udzielenie poparcia prozachodniej opozycji białoruskiej czy jednoznaczne i demonstracyjne poparcie „reżimu Saakaszwilego” w czasie konfliktu rosyjsko-gruzińskiego.

Nie jest tajemnica, że Polska zaczęła upatrywać w Ukrainie jednego z gwarantów swojego bezpieczeństwa, którego istnienie wzmacniałaby stabilność ładu międzynarodowego w Europie. W interesie Polski leżą ponadto dążenia do stworzenia na Ukrainie warunków do przetrwania i rozwoju zachowanych tam polskich reliktów kulturowych i etnicznych. Sprzyjałaby temu ewolucja Ukrainy w kierunku państwa zregionalizowanego i wielonarodowościowego. Tak, aby Ukraina stała się luźną i łatwo przenikalną strefą pograniczną między imperium europejskim a imperium euroazjatyckim (Lasecki, 2015, s. 186-187).

\section{Dzialania wladz polskich wobec kryzysu na Ukrainie}

Zaangażowanie polityków polskich w rozwiązanie konfliktu na Ukrainie uzasadniane było potrzebą obrony tego państwa przed spodziewaną inwazją Rosji. Obierając taktykę wspierania antyrosyjskiego nastawienia części ukraińskich elit i społeczeństwa, łączyło się to automatycznie z popieraniem rządów działających w Kijowie nierzadko łamiących reguły demokracji. W opinii części obserwatorów dyplomacja polska nie stanowiła czynnika łagodzącego kryzys ukraiński, ale odgrywała rolę konfliktującą i przez to coraz mniej jej zdanie liczyło się w globalnej konfrontacji mocarstw. Polska jednoznacznie skrytykowała bowiem aneksję Krymu do Rosji oraz odegrała główną rolę w działaniach na rzecz zwiększenia zaangażowania NATO w krajach wschodniej flanki oraz doprowadzeniu do nałożenia przez UE sankcji na Rosję (Zięba, 2014, s. 22-23). Stawiało to

reprezentujących na emigracji uciśnione narody imperium rosyjskiego", korzystający z moralnego, politycznego i materialnego wsparcia ze strony Polski. Po 1945 r. idea prometejska przetrwała w Maisons-Laffitte pod Paryżem dzięki Jerzemu Giedroyciowi, który w latach 30 . przez pewien czas był związany z tym ruchem. Bezpośrednie odwołania do prometeizmu możemy bez trudu odnaleźć w linii politycznej „Kultury”. Propagowana przez Giedroycia doktryna ULB (Ukraina-Litwa-Białoruś) oznaczała uregulowanie zaszłości historycznych i kwestii granicznych, a także doktrynalne powiązanie kwestii niepodległości Polski z niepodległością naszych wschodnich sąsiadów. Idea ta przenikała do kraju za pośrednictwem publikacji „drugiego obiegu” (Szumiło). 
Polskę w ścisłym gronie państw optujących za twardą odpowiedzią Brukseli na jawnie konfrontacyjną politykę Kremla, obarczając Rosję odpowiedzialnością za destabilizację południowej i wschodniej Ukrainy, dając temu wyraz w mediach europejskich i światowych (Sikorski: Rosja finansuje). Sugerowało to również gotowość Polski do politycznej konfrontacji z Rosją w imię wspólnych, polsko-ukraińskich interesów, co w późniejszym czasie utrudniło Polsce zainteresowanej wpływaniem na wydarzenia na Wschodzie, możliwości realnego i bezpośredniego oddziaływania na bieg wydarzeń w tym kierunku. Jako, że w Polsce znajdują się ważne instalacje wojskowe tj. baza lotnicza w Łasku oraz placówka wojskowa w pobliżu Królewca, a granice państwa polskiego są granicami NATO, Polska stanowiła największe i najważniejsze państwo na pierwszej linii frontu pod względem wojskowym politycznym i gospodarczym.

Od samego początku kryzysu ukraińsko-rosyjskiego w Polsce sprawa Ukrainy traktowana była w sposób priorytetowy o czym świadczyć może chociażby liczba wizyt przedstawicieli polskiej dyplomacji w Kijowie czy uprawiany przez polskich polityków lobbing na rzecz Ukrainy w zagranicznych mediach oraz na forum UE i NATO. Okres największej aktywności, realizowanej przez polską dyplomację w randze ministra oraz wiceministrów, przypadał na czas trwania EuroMajdanu. Pokazem znaczenia Polski w procesie rozwiązania opisywanego konfliktu była głównie aktywna obecność ministra Radosława Sikorskiego w negocjacjach pomiędzy prezydentem Janukowyczem, opozycją i uczestnikami Majdanu, ministrami spraw zagranicznych wybranych państw unijnych oraz specjalnym przedstawicielem Federacji Rosyjskiej. Polska dyplomacja znalazła się zatem w ścisłym gronie kilku państw euroatlantyckich zaangażowanych w rozwiązanie kryzysu polityczno-ustrojowego w państwie ukraińskim.

Cezurą wyznaczającą okres nowej, bardziej restrykcyjnej polityki Unii Europejskiej oraz Stanów Zjednoczonych wobec Rosji, było zestrzelenie przez prorosyjskich separatystów samolotu pasażerskiego malezyjskich linii lotniczych z 298 pasażerami na pokładzie. W odpowiedzi na tragedię szefowie MSZ Polski, Francji i Niemiec wydali komunikat, w którym potępili ów akt terrorystyczny oraz zaapelowali do wszystkich stron biorących udział w konflikcie o doprowadzenie do zawieszenia broni (Wspólne oświadczenie szefów). Tragedia ta stanowiła też przedmiot rozmów m.in. podczas spotkania ministrów Radosława Sikorskiego i Tomasza Siemoniaka z Michaelem Fallonem, ministrem obrony Wielkiej Brytanii, które miało miejsce pod koniec lipca 2014 r. Ustalono wówczas, że Warszawa 
wraz z Londynem będą współpracowały na forum europejskim w dążeniu do nałożenia ostrzejszych sankcji na Federację Rosyjską, obarczając ją odpowiedzialnością za bezprawne działania. We wspólnym komunikacie podkreślono po raz kolejny pełną suwerenność Ukrainy i możliwość dokonania przez nią własnych, niezależnych wyborów w zakresie wyboru autonomicznej drogi na arenie międzynarodowej (Kowalczyk). W trakcie swojego corocznego wystąpienia programowego, będącego najważniejszym wyznacznikiem osiaggnięć, celów i wyzwań stojących przed polską dyplomacją w 2014 r., szef polskiej dyplomacji ostro skrytykował działania Rosji i obiecał zróżnicowane, w tym finansowe, formy wsparcia Kijowa przez Polskę - zarówno w formacie bilateralnym, jak i na forum Unii Europejskiej (Informacja Ministra Spraw Zagranicznych). Próbę dyplomatycznego wpłynięcia na zmianę polityki Rosji podjęto, z udziałem Polski, podczas spotkania Steinmeier-Sikorski-Ławrow. Ważnym gestem było także przyznanie Nagrody Solidarności im. Lecha Wałęsy legendarnemu przywódcy Tatarów Krymskich - Mustafie Dżemilewowi. Była to symboliczna demonstracja poparcia i solidarności dla nowych władz Ukraińskich, a jednocześnie wyraz sprzeciwu wobec ekspansywnych działań Rosji.

Obserwując zaangażowanie strony polskiej na Wschodzie, można odnieść wrażenie, że po pierwszym okresie wzmożonej aktywności władz polskich na Ukrainie, w drugim kwartale 2014 r. strona polska została praktycznie odsunięta od bezpośrednich rozmów na temat rozwiązania konfliktu. Pozbawiono Polskę bezpośredniego wpływu na sytuację dotyczącą bezpieczeństwa u granic RP, nie udało się także przekonać liczących się graczy (głównie Niemiec i Francji) do innego, potencjalnie bardziej korzystnego formatu rozmów, w którym uczestniczyłyby Stany Zjednoczone oraz Unia Europejska jako całość. Proces polityczny regulujący ówczesną sytuację we wschodniej Ukrainie toczył się już w zasadzie bez bezpośredniego udziału Polski m.in.: podczas spotkania w Berlinie (sierpień 2014 r.) ministrów spraw zagranicznych Ukrainy, Rosji, Niemiec i Francji ${ }^{5}$, dotyczącego rozwoju sytuacji we wschodniej Ukrainie. Poseł do Parlamentu Europejskiego z ramienia PO Jacek Saryusz-Wolski, jeden z najbardziej aktywnych na odcinku ukraińskim polskich polityków stwierdził, że Ukraina nie powinna w ogóle zasiadać do stołu rozmów bez udziału Warszawy (Putin nie życzy sobie). Rozczarowanie strony polskiej

5 Tak zwany „format normandzki”, to spotkania szefów dyplomacji Ukrainy, Rosji, Niemiec i Francji, został ustalony 2 lipca 2014 r., podczas obchodów 70. rocznicy lądowania aliantów w Normandii. 
spowodowane brakiem udziału w rozmowach wybrzmiało zresztą kilka dni później, gdy minister R. Sikorski powiedział, że „Polska domaga się, aby ci, którzy wzięli na siebie brzemię odpowiedzialności negocjowania z Rosją - a jest to głównie Republika Federalna Niemiec - zaproponowali, jak można rozwiązać ten konflikt" (R. Sikorski o Ukrainie). We wrześniu zainaugurowany został kolejny „format” rozmów dotyczących rozwiązania konfliktu na wschodniej Ukrainie. Od nazwy miejsca spotkania nazwany został „,formatem mińskim”. W rozmowach uczestniczyli przedstawiciele OBWE, Ukrainy, Rosji oraz (pro)rosyjskich separatystów, którzy po raz pierwszy, od kwietnia, zostali oficjalnie dopuszczeni do rozmów. Doszło też do bezpośredniego spotkania Petra Poroszenki z Władimirem Putinem. W rozmowach mińskich również nie uczestniczyła strona polska, zabrakło też przedstawicieli RFN i Francji.

Po dymisji rządu premiera Donalda Tuska (22 września 2014 r.) na premiera rządu RP zaprzysiężona została dotychczasowa Marszałek Sejmu Ewa Kopacz. Zmiana ta warunkowała również inne personalne przesunięcia. Nowym ministrem spraw zagranicznych został Grzegorz Schetyna. Premier E. Kopacz wyraziła przekonanie, że polskie władze niczym „, dobra matka i kobieta" powinny przede wszystkim chronić swoich obywateli ,zamykając się w domu” i nie narażając Polski na niepotrzebne ryzyko, które - w domyśle - mogłoby być skutkiem zbyt aktywnej pomocy Ukrainie (Kopacz ws. Ukrainy). Premier dodała również, że większe zaangażowanie naszego kraju w pomoc temu państwu będzie możliwe o tyle, o ile zdecydują się na nie wszystkie kraje Unii Europejskiej. Wskazywało to, na zmianę dotychczasowej taktyki Warszawy wobec Ukrainy pomimo deklaracji ministra Grzegorza Schetyny, który wyraził chęć aktywniejszego uczestnictwa Polski w rozwiązywaniu kryzysu ukraińskiego: „format "normandzki' rozmów ukraińsko-rosyjskich się wyczerpał. Teraz potrzebny jest nowy etap. Uważam, że te rozmowy powinny się odbywać z polskim udziałem" (Schetyna: Polska powinna). Tak się jednak nie stało, pomimo klarownych sygnałów wysyłanych z Polski. Kolejne rozmowy w formacie „normandzkim”, które odbyły się 17 października w Mediolanie, również miały miejsce bez udziału Warszawy. Kolejną okazją do dyskusji z partnerami z Niemiec i Francji na temat sytuacji we wschodniej Ukrainie było dla strony polskiej spotkanie Trójkąta Weimarskiego. Do końca 2014 r. Polska nie uczestniczyła już w żadnym spotkaniu o charakterze multilateralnym, dotyczącym kryzysu na Ukrainie.

Ostatni kwartał 2014 r. obejmował jednak kilka istotnych elementów w obszarze dwustronnych relacji na linii Warszawa-Kijów. Podstawy 
polityki zagranicznej nowego rządu na kierunku ukraińskim w 2015 r. zdefiniował 6 listopada w Sejmie minister Grzegorz Schetyna, prezentując swoje wystąpienie programowe. Szef polskiego MSZ oprócz standardowych wyrazów wsparcia zagwarantował wsparcie dla nowego rządu ukraińskiego. Zadania polskiej polityki zagranicznej w zakresie pomocy dla Ukrainy miałoby obejmować m.in. wspieranie reformy samorządowej, wolnych mediów, szkolenie urzędników i wojskowych, pomoc medyczna, przyjęcie młodzieży ukraińskiej na obozy i kolonie etc. Warto też podkreślić, że Warszawa ma w 2015 r. konsekwentnie opowiadać się za implementacją Umowy Stowarzyszeniowej między Ukrainą a UE w niezmienionej formie, $\mathrm{tj}$. wynegocjowanej i już podpisanej - nie zważając na głosy krytyki ze strony Kremla (Informacja Rady Ministrów).

Było to rozpoczęcie, z końcem 2014 r., procesu przygotowywania ewakuacji Polaków z terenów objętych lub zagrożonych walkami we wschodniej Ukrainie. Polskie władze zadeklarowały pomoc, a w zasadzie kierowniczą rolę w przeprowadzeniu tego przedsięwzięcia. Pomimo obietnic i zapewnień strony polskiej, ewakuacja jednak nie została przeprowadzona. Jej termin był kilkukrotnie zmieniany przez stronę rządową. Najdonioślejszym wydarzeniem w drugiej połowie roku, jeśli chodzi kontakty polityczne, była oficjalna, dwudniowa wizyta prezydenta Ukrainy Petra Poroszenki w Polsce. Wizyta głowy państwa ukraińskiego nie przełożyła się na wymierne efekty takie jak podpisanie konkretnych umów handlowych czy dokumentów dotyczących współpracy gospodarczej, intensyfikacja współpracy instytucjonalnej, sygnowanie umów dyplomatycznych lub strategicznych itp. Tym niemniej spotkanie Petra Poroszenki z Bronisławem Komorowskim zaowocowało deklaracjami politycznymi. Na wspólnej konferencji prasowej prezydent RP podtrzymał główne założenia polityki polskiej wobec Ukrainy tj. wsparcie dla integralności terytorialnej, pełnej suwerenności oraz innych atrybutów niepodległości państwa ukraińskiego. Oprócz tego zapewnił o podtrzymaniu przez Warszawę chęci wsparcia strukturalnych reform gospodarczych, politycznych, instytucjonalnych czy reorganizacji wymiaru sprawiedliwości nad Dnieprem. Prezydent Komorowski poparł aspiracje Ukrainy w zakresie realnego zbliżania się do struktur euroatlantyckich. Zapewnił też, że Polska nie wycofa się ze swoich zobowiązań w zakresie wspierania modernizacji armii ukraińskiej podjętych w trakcie szczytu NATO w Newport, a także z obietnicy możliwości sprzedaży nad Dniepr uzbrojenia i potrzebnych komponentów militarnych. Prezydent Poroszenko w trakcie konferencji prasowej po spotkaniu prezydentów podkreślił, że 
Ukraina liczy na pomoc Polski w obszarze wsparcia sanacji ukraińskiego państwa (Komorowski: Jesteśmy gotowi). Warto podkreślić ważne, choć symboliczne sformułowanie ukraińskiego prezydenta: „Chciałbym podziękować Panu Prezydentowi za gościnność, nieugiętą proukraińskość. Polska jest największym adwokatem Ukrainy w Unii Europejskiej, za co niezmiernie dziękuję" (Poroszenko: Polska największym). Doniosłym fragmentem wizyty P. Poroszenki w Polsce było również jego wystąienie w Sejmie, które uwzględniało w sobie elementy wpisujące się w trudny, polsko-ukraiński dialog historyczny. W kontekście rzezi wołyńskiej oraz akcji „Wisła” prezydent Ukrainy zastosował znaną z polskiej historii formułę „wybaczamy i prosimy o wybaczenie" (Poroszenko w Polskim Sejmie).

W opinii części obserwatorów jednym z bezpośrednich efektów aktywności Polski na Ukrainie było jednak zaostrzenie sytuacji międzynarodowej z poważnymi konsekwencjami dla bezpieczeństwa Polski. Jako główne zagrożenie dla bezpieczeństwa narodowego powszechnie uznano interwencję Rosji w sprawy ukraińskie. Dlatego też rząd polski wspierany przez opozycję, wykorzystał sytuację dla wzmacniania solidarności w ramach NATO i UE, uzyskując jednocześnie potwierdzenie gwarancji bezpieczeństwa ze strony Sojuszu i Stanów Zjednoczonych. Uznano bowiem, że odbudowywanie mocarstwowej pozycji przez Rosję kosztem jej otoczenia oraz nasilenie przez nią polityki konfrontacyjnej (konflikt na Ukrainie) będzie negatywnie rzutować na stan bezpieczeństwa w regionie.

Pozytywną konsekwencją zaangażowania Polski na Wschodzie był wzrost międzynarodowej pozycji Polski. Polska miała niewątpliwie znaczny udział we wspieraniu ukraińskich aspiracji europejskich i kijowskiego EuroMajdanu. Nie udało się jednak stworzyć porozumienia na miarę ukraińskiego „okragłego stołu”, jak to miało miejsce kiedyś w Polsce, ale podjęto wiele działań w kierunku stworzenia płaszczyzny porozumienia między zwaśnionymi krajami. Dyplomacja polska podejmowała działania zmierzające do kompromisowego rozwiązania kryzysu ukraińskiego, starając się nie angażować Rosji w ten proces. Efektem tych wysiłków było doprowadzenie przez ministrów spraw zagranicznych Trójkąta Weimarskiego (Polski, Francji, Niemiec) do podpisania, w obecności przedstawiciela Rosji, porozumienia między prezydentem Janukowyczem a liderami głównych ukraińskich partii opozycyjnych (21 lutego 2014 r.) (Stolarczyk, 2014, s. 55). Ukraiński Majdan odrzucił bowiem porozumienie z prezydentem Janukowyczem, a władze polskie skoncentrowały się na wspieraniu rewolucyjnej władzy w Kijowie, potę- 
pianiu rosyjskiej ingerencji i organizowaniu sankcji Zachodu przeciwko Rosji. Zdaniem części obserwatorów Polska nie występowała już jako państwo szukające porozumienia w sprawie ukraińskiej, co może mieć negatywny wpływ na rozwój stosunków polsko-rosyjskich w przyszłości np. embargo na import polskich owoców i warzyw w sierpniu 2014 r. nałożone przez Rosję. Ważną konsekwencją, która może objawić się dopiero w przyszłości jest fakt, że Polska jest sąsiadem niestabilnego państwa ukraińskiego. Problemy gospodarcze Ukrainy i wynikające z nich problemy społeczne, mogą prowadzić do możliwej presji migracyjnej na Polskę. Ukraina niezależnie od rozwoju sytuacji nadal będzie trudnym sąsiadem Polski, a jej problemy wewnętrzne będą stawiać Polskę przed dużymi wyzwaniami.

Warto zauważyć ponadto, że popierani przez polską klasę polityczną liderzy Majdanu występowali z projektem integracji Ukrainy z Zachodem w imieniu wszystkich Ukraińców. Nie doceniali jednak skali podziałów występujących w społeczeństwie ukraińskim. Klasa polityczna oraz polskie media, zdecydowanie i bezkrytycznie popierały wszystkie działania coraz bardziej radykalizującego się Majdanu. Polscy politycy przemawiali do manifestujących na Majdanie, zagrzewali ich do oporu przeciwko legalnej władzy i obiecywali Ukraińcom szybkie przystapienie do UE. Tak szerokie wsparcie ze strony polskiej klasy politycznej dla opozycji w Kijowie, mogło zostać odebrane przez nią jako zachęta do podejmowania kolejnych niekonstytucyjnych działań. Politycy żadnego innego państwa nie zaangażowali się tak bezpośrednio, w takiej skali i z taką intensywnością jak polscy. Celem tej polityki było wyrugowanie wpływów rosyjskich na Ukrainie. Aneksja Krymu przez Rosję, zaostrzyła jednak stanowisko dyplomacji polskiej, która należała do grupy państw domagających się nałożenia na Rosję dotkliwych sankcji.

W opinii niektórych obserwatorów zaskakiwał brak wyobraźni polskich władz, większości polskich analityków oraz większości polskiego środowiska dziennikarskiego w kwestii konsekwencji realizacji coraz bardziej radykalnych postulatów Majdanu. Polskie elity polityczne i intelektualne - wśród których dominowało przekonanie, że najlepiej ze wszystkich krajów UE i NATO rozumieją i znają specyfikę państw obszaru Wspólnoty Niepodległych Państw (WNP) - w pełni akceptowały występowanie liderów Majdanu w imieniu całego społeczeństwa ukraińskiego, mimo że znaczna część tego społeczeństwa nie zgadzała się z ich programem (antyrosyjskością, szybką integracją Ukrainy z UE, członkostwem w NATO). Politycy polscy nie dostrzegali, że ra- 
dykalizacja nastrojów protestujących i reakcja władz, w tym wykorzystywanie policji do spacyfikowania protestujących na Majdanie, mogą doprowadzić do konfliktu wykraczającego poza Kijów czy wręcz do wojny domowej na Ukrainie, której konsekwencją może być podział tego państwa. Politycy polscy zamiast poprzeć ewolucyjne przemiany na Ukrainie, zdecydowanie opowiedzieli się za „rewolucyjnym przyspieszeniem", nie zdając sobie sprawy jakie negatywne konsekwencje może to mieć nie tylko dla Ukrainy, ale i dla Polski oraz dla sytuacji międzynarodowej w Europie.

Działania podejmowane przez większość polskich polityków w kolejnych miesiącach protestów na Majdanie wynikały nie tyle $\mathrm{z}$ dążenia do stabilizacji sytuacji na Ukrainie, poprawy poziomu życia społeczeństwa tego kraju oraz przebudowy systemu politycznego i ekonomicznego naszego sąsiada, ale z przekonania, że jest to dogodny moment by osłabić, a nawet wyeliminować wpływy Rosji na Ukrainie i ostatecznie wygrać rywalizację z Rosją o ten kraj. W Polsce dominowało bowiem stanowisko, do chwili aneksji Krymu przez Rosję, że do rozwiązania kryzysu na Ukrainie nie należy dopuszczać Rosji (Stolarczyk, 2014, s. 56-57). Dla grup rządzących w Rosji zaangażowanie Polski, USA i innych państw zachodnich w poparcie dla EuroMajdanu było kolejnym etapem polityki osłabiania Rosji i ograniczania jej wpływów na obszarze byłego Związku Radzieckiego (Stolarczyk, 2014, s. 55).

\section{Podsumowanie}

Kryzys 2013-2014 i jego implikacje okazały się efektem trwającej od wielu lat geopolitycznej rywalizacji mocarstw o poszerzenie wpływów na Ukrainie. Kolejne etapy sporu to przede wszystkim wynik braku woli porozumienia wśród ukraińskich elit oraz efekt polityki Rosji, USA i UE prowadzonej wobec Ukrainy. Nie jest to proces zakończony i należy się liczyć z kolejnymi kryzysami w tym kraju (Stolarczyk, 2014, s. 87). Wydaje się, że z geopolitycznego punktu widzenia Ukraina skazana jest na dalszą wielowektorowość. Kształtowanie polityki zagranicznej poprzez opcję Wschód-Zachód jest nie tylko drogą wyboru, ale przede wszystkim istotną potrzebą modernizacji państwa poprzez współpracę z Rosją i Unią Europejską. Każda ze stron wchodząc w relacje z Ukrainą, chce ją zachęcić do integracji, mając na uwadze głównie swój interes. Dla UE państwo ukraińskie stanowić może ,pas” bezpieczeństwa, stabilności i rozwoju, 
a w dalszej perspektywie istotną część demokratycznego ładu w Europie Wschodniej. Z kolei dla Rosji Ukraina stanowi znaczący czynnik w odbudowie jej mocarstwowości, a także z uwagi na geostrategiczną rolę Ukrainy w obszarze Morza Czarnego. Federacja Rosyjska usiłuje ponadto nie tylko integrować w państwa byłego ZSRR, ale także konkurować z Zachodem o wpływy w regionie Euroazji.

W polityce polskiej 2014 r. kwestia Ukrainy od samego początku traktowana była w sposób priorytetowy. Wynikało to z podstawowych założeń polityki zagranicznej, w której traktowano umacnianie niepodległości i zachodniego kursu w polityce zagranicznej Ukrainy jako jednej z podstawowych gwarancji, że Rosja nie powróci do polityki imperialnej. Rosję traktowano w Polsce jako główne zagrożenie bezpieczeństwa, a konsekwencją tego była polityka odpychania Rosji od Europy, odgradzania jej pasem buforowym w postaci prozachodnich państw na naszej wschodniej granicy.

Odpowiadając na pytanie o główne konsekwencje zaangażowania Polski w kryzys na Ukrainie należy zauważyć, że sytuacja na Wschodzie odegrała istotną rolę $\mathrm{w}$ podtrzymywaniu poczucia zagrożenia ze strony Federacji. W społeczeństwie polskim umocniły się, od lat dominujące postawy antyrosyjskie, będące efektem trudnych doświadczeń kolejnych pokoleń Polaków w relacjach z Rosją. Sytuacja na Ukrainie paradoksalnie zadziałała również na korzyść Polski. W efekcie zagrożenia wywołanego konfliktem na Wschodzie wzrosła tendencja w kierunku wzmacniania bezpieczeństwa poprzez rozwijanie własnego potencjału obronnego, nastąpił również wzrost poparcia społecznego dla zwiększenia wydatków na obronność (Talaga, 2014). W kontekście bezpieczeństwa podjęto również współpracę z innymi państwami poprzez ściślejsze współdziałanie w ramach zobowiązań sojuszniczych (Stolarczyk, 2014, s. 65). Nastąpiło ponadto wzmocnienie spoistości działań w ramach NATO i wzrost jego zaangażowania w bezpieczeństwo Polski i regionu oraz wewnętrzna konsolidacja Sojuszu. Kryzys wpłynął również na wzrost poparcia polskiego społeczeństwa dla członkostwa Polski w NATO (Kowalczuk, 2014, s. 4). Zaobserwowano również wzrost zainteresowania USA kwestiami bezpieczeństwa europejskiego.

Kryzys ukraiński, obok niekwestionowanych korzyści, ujawnił także obawy dotyczące bezpieczeństwa jako takiego oraz jego wymiaru ekonomicznego. Pomimo, że uzależnienie polskiej gospodarki od importu rosyjskiego gazu było znacznie mniejsze, niż w przypadku wielu państw europejskich, politycy polscy artykułowali obawy związane z zagroże- 
niem bezpieczeństwa energetycznego UE, związane z nadmiernym uzależnieniem od dostaw rosyjskiego gazu.

Rola państwa polskiego dla wyboru przez Ukrainę zachodniej drogi rozwoju jest znacząca. Jednak skuteczność działań w tym kierun$\mathrm{ku}$ ograniczona jest poprzez barierę geopolityczną, która sprawia, że Ukraina poddawana jest permanentnej polityce Rosji, która nie dopuszcza, aby znalazła się ona poza strefą jej wpływów. Czynnik geoekonomiczny blokuje prozachodnią drogę Ukrainy, powodując że niektórzy członkowie UE (Niemcy, Francja) w obawie przed negatywną reakcją Rosji wykonują jedynie pozorne ruchy na rzecz akcesji Ukrainy do UE. Również element świadomościowy wpływa negatywnie na integrację Ukrainy z Zachodem, bowiem występuje zarówno wśród części elit politycznych, jak i społeczeństwa ukraińskiego, uniemożliwiając konsekwentne przemiany systemowe, ustrojowo-prawne w drodze do pełnego stowarzyszenia z UE. Ocena zaangażowania władz polskich na Ukrainie nie jest jednak jednoznaczna. Część obserwatorów doceniła pracę, jaką wykonali polscy politycy na Ukrainie oraz na forum europejskim. Byli też i tacy, którzy traktowali zaangażowanie Polski na Wschodzie za zbędne, niewłaściwie ingerujące w sprawy innego państwa, a w konsekwencji działanie pogarszające, i tak już skomplikowane, stosunki z Rosją. Jednym z najważniejszych następstw kryzysu i konfliktu ukraińskiego dla Polski była utrata poczucia bezpieczeństwa obywateli. Potwierdzali to przedstawiciele partii rządzących w Polsce (Informacja Ministra Spraw Zagranicznych), ugrupowań opozycyjnych oraz analitycy spraw międzynarodowych i publicyści. Stanowisko takie podzielała również, jak pokazują badania sondażowe, większość społeczeństwa polskiego (Omył-Rudzka, 2014, s. 2). Spadek poczucia bezpieczeństwa w opinii części obserwatorów jest w znacznym stopniu następstwem polityki władz polskich wobec Ukrainy i Rosji, w tym bezgranicznego i jednostronnego poparcia dla wszystkich działań, nawet tych niezgodnych z prawem Ukrainy, podejmowanych przez EuroMajdan.

Sytuacja polityczna na Ukrainie wydaje się dość skomplikowana. Brak tradycji własnej państwowości, skorumpowane rządy, gospodarka rozparcelowana pomiędzy grupy interesów - wszystko to przez lata niszczyło kraj, drenowało z zasobów ludzkich (wielomilionowa emigracja), bogactw naturalnych czy środków finansowych. EuroMajdan narodził się na tych mocno nadwyrężonych fundamentach, pogłębiając jeszcze bardziej słabość państwa ukraińskiego. Klasa oligarchów powstała na 
uwłaszczonym majątku poradzieckim - przemyśle wschodniej i centralnej Ukrainy, na zasobach naturalnych kraju, potężnej branży gazowej. Przenikanie się elit politycznych i prywatnego biznesu stworzyło splątany węzeł zależności i korupcji (Szczęśniak).

Najbliższe lata będą stanowić dla Ukrainy spore wyzwanie. Zniszczone instytucje państwowe, uzbrojone radykalne grupy polityczne sięgające po władzę, teren realizacji partykularnych interesów mocarstw światowych, rozszerzający się obszar biedy, wysokie bezrobocie. W tych warunkach bardzo prawdopodobny staje się rozwój i eksport agresji i terroryzmu. I chociaż będzie on skierowany przeciw Rosji, to jednak odłamki moga uderzać także w Polskę. Więzi kooperacyjne przemysłu z Rosją będą się rwać, w efekcie czego rosnąć będzie bezrobocie. Społeczeństwo żyjące na najniższym poziomie w Europie może prowokować bunty i nasilenie się w nim agresji. Radykalne reformy w czasie zbrojnego konfliktu i politycznego chaosu to prosta recepta na klęskę całego kraju. Przed Ukrainą nie widać jasnych perspektyw. Jedynym wyjściem z kryzysu, byłoby porozumienie realnych aktorów tego konfliktu - Stanów Zjednoczonych i Rosji. Jednak Ukraina jest dla Rosji zbyt żywotnym punktem bezpieczeństwa i zbyt atrakcyjnym miejscem dla Ameryki, próbującej osłabiać Rosję, aby takie porozumienie miało szanse powodzenia (Szczęśniak). Wydaje się, że sytuacja na Ukrainie doszła do punktu, z którego nie ma już odwrotu, ani tym bardziej praktykowanej od lat strategii „trzeciej drogi” między Rosją a Zachodem. W obecnej sytuacji Kreml ma w zasadzie dwa wyjścia. Po pierwsze - utrzymywać na Ukrainie stan permanentnego chaosu i wrzenia wewnętrznego, włącznie z perspektywą otwartej wojny domowej, co skutecznie zniechęciłoby UE do jakiejkolwiek myśli o włączeniu tego kraju w swe struktury. Po drugie - Rosjanie mogą jednak uznać realia geopolityczne, które dają bardzo małe szanse na utrzymanie Ukrainy z dala od Zachodu i tym samym rozpoczać grę na podział tego państwa (Otłowski, 2015, s. 202).

\section{Bibliografia}

Barburska O. (2006), Polska wobec europejskich aspiracji Ukrainy, w: Rola Polski w ksztattowaniu polityki wschodniej Unii Europejskiej na przyktadzie Ukrainy, red. J. Borkowski, Warszawa.

Brzezinski Z. (1997), The Grand Chessboard: American Primacy and its Geostrategic Imperatives, New York. 
Brzeziński Z. (1998), Wielka szachownica. Główne cele polityki amerykańskiej, Warszawa.

Genewskie porozumienie ws. Ukrainy - czas pokaże, na ile jest wiarygodne, http:// wyborcza.pl/1,91446,15821388,Genewskie_porozumienie_ws_Ukrainy czas_pokaze_html, 15.12.2015.

Informacja Ministra Spraw Zagranicznych o zadaniach polskiej polityki zagranicznej w 2014 r., http://www.msz.gov.pl/pl/aktualnosci/wiadomosci/informacja_ministra_spraw_zagranicznych_o_zadaniach_polskiej_polityki_zagranicznej_w_2014_roku, 15.03.2016.

Informacja Rady Ministrów o zadaniach polskiej polityki zagranicznej $w$ latach 2014-2015, http://goo.gl/o8cgyw, 15.03.2016.

Komorowski: Jesteśmy gotowi sprzedawać Ukrainie broń, http://www.tvn24.pl/wideo/komorowski-jestesmy-gotowi-sprzedawac-ukrainie-bron, 1372081.html, 15.03.2016.

Kopacz ws. Ukrainy: Polska powinna się zachowywać jak rozsqdna kobieta, http:// www.tvn24.pl/wiadomosci-z-kraju,3/polska-powinna-byc-jak-rozsadna-kobieta-kopacz-o-sprawach-miedzynarodowych,469729.html, 15.03.2016.

Kowalczuk K., Polacy o bezpieczeństwie narodowym i NATO. Komunikat z badań CBOS, $n r$ 48/2014, Warszawa, kwiecień 2014 r., http://www.cbos.pl/SPISKOM.POL/2014/K_048_14.PDF, 15.03.2016.

Kowalczyk A. (2015), Polityka Polski wobec Ukrainy w 2014 roku - próba bilansu, „Biuletyn OPINIE” FAE, nr 3, http://fae.pl/biuletynopiniefaerpukraina2014. pdf, 15.12.2015.

Kuczyński G., Genewska pułapka. Jak rosyjska dyplomacja ograła Zachód i Ukrainę, http://www.tvn24.pl/wiadomosci-ze-swiata,2/genewska-pulapka-jak-rosyjska-dyplomacja-ograla-zachod-i-ukraine,456273.html, 15.12.2015.

Lasecki R. (2015), Ukraina na geopolitycznym rozdrożu, w: Formatowanie Ukrainy. Antologia publikacji portalu ,, Geopolityka.org”, t. 1: W cieniu EuroMajdanu (21 XI 2013-27 VI 2014), red. M. Domagała, R. Potocki, Warszawa.

Omył-Rudzka M., Stosunki polsko-ukraińskie w opinii Polaków. Komunikat z badań CBOS nr 95/2014, Warszawa, lipiec 2014, http://www.cbos.pl/SPISKOM. POL/2014/K_095_14.PDF, 15.03.2016.

Otłowski T. (2015), Konflikt na Ukrainie - aspekty geopolityczne, w: Formatowanie Ukrainy. Antologia publikacji portalu ,Geopolityka.org”, t. 1: W cieniu EuroMajdanu (21 XI 2013-27 VI 2014), red. M. Domagała, R. Potocki, Warszawa.

Poroszenko w Polskim Sejmie: wybaczamy i prosimy o wybaczenie, http://polska. newsweek.pl/petro-poroszenko-w-polskim-sejmie-wizyta-poroszenki-newsweek-pl,artykuly,353753,1.html, 15.03.2016.

Poroszenko: Polska największym adwokatem Ukrainy w UE, http://wiadomosci. onet.pl/kraj/poroszenko-polska-jest-najwiekszym-adwokatem-ukrainy-wue/5q821, 15.03.2016. 
Potocki R. (2014), EuroMajdan jako zagadnienie badawcze, w: Czas EuroMajdanu, red. R. Potocki, M. Domagała, D. Miłoszewska, Warszawa.

Putin nie życzy sobie Polski przy stole, http://wiadomosci.wp.pl/kat,1342,title,JacekSaryusz-Wolski-Putin-nie-zyczy-sobie-Polski-przy-stole,wid,16820158,wiadomosc.html?ticaid=116dda\&_ticrsn=5, 15.03.2016.

R. Sikorski o Ukrainie: Merkel chciała negocjować z Putinem. Niech rozwiaże ten konflikt, http://www.gazetaprawna.pl/artykuly/819065,sikorski-o-ukrainiemerkel-chciala-negocjowac-z-putinem-niech-rozwiaze-ten-konflikt.html, 15.03.2016.

Referendum na Krymie: 96,8 proc. za przyłaczeniem do Federacji Rosyjskiej, http://wiadomosci.onet.pl/swiat/referendum-na-krymie-96-8-proc-zaprzylaczeniem-do-federacji-rosyjskiej/hrdrc, 15.12.2015.

Schetyna: Polska powinna wrócić do negocjacyjnego stołu w sprawie Ukrainy, http:// wyborcza.pl/1,76842,16762052,Schetyna_Polska_powinna_wrocic_do_negocjacyjnego.html?disableRedirects=true, 15.03.2016.

Sikorski: Rosja finansuje działania wywrotowe na Ukrainie, http://www.tvn24.pl/ wiadomosci-ze-swiata,2/sikorski-rosja-finansuje-dzialania-wywrotowe-naukrainie,416634.html, 15.04.2016.

Stolarczyk M. (2014), Dylematy bezpieczeństwa Polski w kontekście kryzysu i konfliktu ukraińskiego w latach 2013-2014, w: Dylematy polityki bezpieczeństwa Polski na poczatku drugiej dekady XXI wieku, red. K. Czornik, M. Łakomy, Katowice.

Szczęśniak A., Ukraina - epicentrum międzynarodowej rywalizacji, http://nowadebata.pl/2014/06/23/ukraina-epicentrum-miedzynarodowej-rywalizacji/, 15.03.2016.

Szumiło M., Polski prometeizm w XX-XXI wieku, http://historia.org.pl/2014/07/18/ polski-prometeizm-w-XX-Xxi-wieku/, 23.05.2016.

Świder K., Geopolityczne uwarunkowania trwałości i nietrwałości postradzieckiego państwa ukraińskiego (2014), „Rocznik Instytutu Europy ŚrodkowoWschodniej”, R. 12, z. 5.

Talaga A., Warto wydawać na wojsko, „Gazeta Wyborcza”, 5.04.2014.

Tymanowski J. (2014), Ukraina między Wschodem a Zachodem, Warszawa.

UE rozszerza sankcje wobec Rosji, http://wyborcza.pl/1,91446,16336457,UE_rozszerza_sankcje_wobec_Rosji.html, 15.12.2015.

Wspólne oświadczenie szefów MSZ „Jesteśmy wstrzqśnięci tragicznq katastrofa samolotu”, http://www.tvn24.pl/wiadomosci-z-kraju,3/wspolne-oswiadczenieszefow-msz-jestesmy-wstrzasnieci-tragiczna-katastrofa-samolotu, 451396. html, 15.04.2016.

Zięba R. (2014), Międzynarodowe implikacje kryzysu ukraińskiego, „Studia Międzynarodowe", t. 50, $\mathrm{nr} 2$. 
Geopolitical context of the crisis in Ukraine (2013-2014) and the Polish authorities' commitment to solve it

\section{Summary}

The paper presents the specifics of the involvement of international actors in the conflict of Ukraine at the turn of 2013-2014. The country was considered attractive primarily due to its geopolitical position and the country being a buffer between the East and the West. The steps taken by the Polish authorities in the settlement of a dispute arising from the growing sense of threat from the Russian Federation are also discussed.

Key words: the crisis in Ukraine (2013-2014), Euromaidan, geopolitics 